sa niêu quản có 1 trường hợp túi sa niệu quản lớn đường kính $3 \mathrm{~cm}$ đã mở túi sa trước khi cắt đơn vị thận, 2 trường hợp còn lại có đường kính túi sa lần lượt là 1,8 và $1,6 \mathrm{~cm}$ sau khi phẫu thuật cắt đơn vịt thận trên đã không ghi nhận còn túi sa niệu quản trên lâm sàng hoặc siêu âm. Với kinh nghiệm của mình chúng tồi ưu tiên phẫu thuật cắt bỏ đơn vị thận trên trước, mở túi sa niệu quản được chỉ định trước mổ nếu túi sa lớn gây đái khó hoặc bí đái.

Chúng tôi có 2 trường hợp có tồn tại nang cực trên thận không triệu chứng với đường kính là 9 và $20 \mathrm{~mm}$. Báo cáo của các tác giả khác trên thế giới cũng ghi nhận nang cực trên thận không triệu chứng. Hiorns và cộng sự đã mô tả tỉ lệ hình thành nang nhỏ ở vị trí của thận trên sau phẫu thuâtt là $60 \%$ và $80 \%$ các nang dịch này hoàn toàn không có triệu chứng [7]. Với 2 trường hợp nang cực trên thận trong nghiên cứu, chúng tôi chưa ghi nhận bất cứ triệu chứng nào, kết quả chụp xa hình thận sau mổ cũng không ghi nhận bất thường. Báo cáo của tác giả Gundeti MS cũng ghi nhận tỉ lệ $6,8 \%$ có tổn thương đơn vị thận dưới sau phẫu thuât cắt đơn vị thân trên với cả các trường hợp mổ mở hoăc nội soi [8]. Trong 20 bệnh nhân của nghiên cứu có 2 trường hợp có biểu hiện giãn của bể thận đơn vị thận dưới lần lượt là 8 và $13 \mathrm{~mm}$. Chúng tôi đã tiến hành chụp lại xa hình thân sau phẫu thuât ở các bênh nhẩn này, kết quả không có tổn thương nhu mô thận dưới, thuốc lưu thông bình thường qua hệ tiết niệu. Mặc dù cần có thời gian theo dõi lâu dài hơn nhưng bước đầu có thể thấy phẫu thuật nội soi qua phúc mạc cắt đớn vị thận trên hầu như không có biến chứng đặc biệt nào.

\section{KẾT LUÂN}

Phẫu thuật nội soi qua phúc mạc cắt đơn vị thận trên mất chức năng trong điều trị thận niệu quản đôi hoàn toàn ở trẻ em là an toàn và hiệu quả.

\section{TÀI LIẸU THAM KHẢO}

1. Jordan GH, Winslow BH (1993). "Laparoendoscopic upper pole partial nephrectomy with ureterectomy". J Urol,150,940-943.

2. Whitten SM, Wilcox DT (2001). Duplex systems. Prenat Diagn, 21,952-7.

3. Nguyê̂n Viêt Hoa, Vũ Hônng Tuân (2018). "Nôi soi sau phúc mạc cắt thận phụ mât chức năng trong thận niệu quản đôi: Kinh nghiệm 31 trường hợp".Tap chí y học Viêtt Nam, số 1 tháng 6, 132-137.

4. Leclair MD, Vidal I et al (2009). "Retroperitoneal laparoscopic heminephrectomy in duplex kidney in infants and children: a 15-year experience". Eur Urol, 56, 385-389.

5. Castellan M, Gosalbez $R$ et al (2006). "Transperitoneal and retroperitoneal laparoscopic heminephrectomy-what approach for which patient?". J Urol, 176, 2636-2639.

6. Borzi PA, Yeung CK (2004). "Selective approach for transperitoneal and extraperitoneal endoscopic nephrectomy in children". J Urol, 171 , 814-816.

7. Hiorns MP, Mazrani W et al (2008). "Follow-up imaging after laparoscopic heminephrectomy in children". Pediatr Radiol, 38, 762-765.

8. Gundeti MS, Ransley PG et al (2005)." Renal outcome following heminephrectomy for duplex kidney". J Urol, 173,1743-1744.

\title{
ĐĂC ĐIỂM LÂM SÀNG, CÂN LÂM SÀNG NGộ ĐộC MộT Số MA TÚY TẠI TRUNG TÂM CHỐNG ĐộC BỆNH VIỆN BẠCH MAI
}

\section{TÓM TẮT}

Mục tiêu: Mô tả đặc điểm lâm sàng, cân lâm sàng của bệnh nhân ngộ độc ma túy không phải nhóm opi tại Trung tâm Chổng độc Bệnh viện Bạch Mai. Đối tượng và phương pháp: Nghiên cứu mô tả $72 b$ ệnh nhẩn ngộ độc ma túy không phải nhóm opiđiều trị tại Trung tâm Chống độc Bệnh viện Bạch Mai từ tháng 1/2017 đến 6/2019. Kết quả: Loại ma túy thường

${ }^{1}$ Trung Tâm Chông Độc - Bệnh viện Bạch Mai

2Bệnh viện Lão khoa Trung ương

Chiu trách nhiệm chính: Đăng Thị Xuân

Email: xuandangthi@bachmai.edu.vn

Ngày nhận bài: 5.3.2021

Ngày phản biên khoa học: 26.4.2021

Ngày duyệt bài: 5.5.2021

\section{Đặng Thị Xuân1, Nguyễn Trung Anh²}

găp: Amphetamin (29,2\%), MET (22,2\%), MDMA $(19,4 \%)$, THC $(20,8 \%)$, Ketamin $(8,3 \%)$. Đặc điểm lâm sàng chủ yếu về tim mạch và thần kinh trung ương trong hội chứng cường giao cảm và hội chứng serotonin: nhịp tim nhanh $(73,6 \%)$, tăng huyết áp $(45,8 \%)$,sốt $(43,1 \%)$; Rối loạn ý thức $100 \%$ (kích thích $58,3 \%$, vật vã $23,6 \%$ và $18,1 \%$ lẫn lộn/hôn mê); tăng tiết mồ hổi $(77,8 \%)$, giãn đồng tử $(59,7 \%)$, tăng trương lực cơ $(55,6 \%)$, tăng phản xạ gân xương $(47,2 \%) ; 84,7 \%$ có hôi chứng serotonin. Cân lâm sàng: tăng bạch câu $(41,7 \%)$, tăng CK $(38,9 \%)$, tiêu cơ vân $(13,9 \%)$, suy thận cấp $(12,5 \%)$, tăng troproninT $10 \%$. Kết luận: Đánh giá đặc điểm lâm sàng và cân lâm sàng của ngộ độc ma túy cần thiết để chẩn đoán và xử trí cấp cứu cho các bệnh nhân.

Từ khóa: ngộ độc ma túy 


\section{SUMMARY}

CLINICAL AND LABORATORY CHARACTERISTICS OF PATIENTS WITH DRUGS OF ABUSE POISONING AT POISON CONTROL CENTER BACHMAI HOSPITAL

Objective: to assess clinical and laboratory characteristics of patients with non-opium drugs of abuse poisoning. Subjects and Methods: A observational study included 72 poisoned non-opium drug poisoning patientstreated at Poison Control Center Bach Mai Hospital from 1/2017 to 6/2019. Results: Common non-opium drugs of abuse: Amphetamine $(29.2 \%)$, MET $(22.2 \%)$, MDMA $(19.4 \%)$, THC $(20.8 \%)$, Ketamin $(8.3 \%)$. The main clinical features of cardiovascular and central nervous system in sympathomimetic and serotonin syndromes: tachycardia (73.6\%), increased blood pressure $(45.8 \%)$, fever $(43.1 \%)$; Consciousness disorder $100 \%$ (stimulus $58.3 \%$, struggling $23.6 \%$ and $18.1 \%$ confusion/coma), increased sweating $(77.8 \%)$, dilated pupils $(59.7 \%)$, increased muscle tone $(55.6 \%)$, increased tendon reflexes $(47.2 \%) ; 84.7 \%$ have serotonin syndrome. Laboratory: leukocytosis $(41.7 \%)$, increased CK(38.9\%), rhabdomyolysis $(13.9 \%)$, acute renal failure $(12.5 \%)$, increased troproninT $(10 \%)$. Conclusion: the evaluation of clinical and laboratory characteristics in patients with drugsof abuse poisoning is essential for early diagnosis and management of patients.

Key words: drugs of abuse poisoning

\section{I. ĐẶT VẤN ĐỀ}

Ma túy là các chất gây nghiện, chất hướng thần, gây nên nhiều hệ lựy ở các nước trên thế giới. Theo báo cáo của tố chức Phòng chống ma túy và tội phạm Liên Hợp Quốc, hiện tại ước tính có từ 167 đến 315 triệu người nghiện ma túy trên thế giới. Tại châu Á, tỉ lệ người nghiện ma túy không cao, nhưng với dân số đông, số lượng người nghiện ma túy vẫn chiếm tới hớn $40 \%$ số người nghiện trên toàn thế giới. Vùng Đông và Đông Nam châu Á có tỉ lệ người nghiện chích ma túy cao nhất, chiếm $27 \%$ tổng số người nghiện chích toàn thế giới [1].

Nghiện ma túy tại Việt Nam vẫn đang diễn biến phức tạp với chiều hướng ngày càng gia tăng. Năm 1994 có số người nghiện chích ma túy là 55445 người, thì tính đến 12/2013, cả nước có trên 180000 người nghiện ma túy, số người nghiện đang ở cộng đồng chiếm tỷ lệ $64,5 \%[2]$. Trước đây Heroin (nhóm opi) là chất gây nghiện chiếm $3 / 4$ chất gây nghiện thường được sử dụng. Tuy nhiên, thời gian gần đây các loại ma túy mới không phải nhóm opi được sử dụng ngày càng nhiều, như các loại ma túy tổng hợp bao gồm amphetamin và dẫn xuất, lá khát, cần sa, ketamin, lysergic acid diethylamid (LSD), $\mathrm{N}_{2} \mathrm{O}, \ldots$
Tại Trung tâm Chống độc Bệnh viện Bạch Mai trước đây cấp cứu rất nhiều các bệnh nhân quá liều heroin, gần đây ngộ độc ma túy tổng hợp, cần sa, ketamin... gặp ngày càng nhiều, triêuu chứng ngộ độc phức tạp, nhiêu bệnh nhân kích động, "ngáo đá", gây nguy hại cho bản thân và người xung quanh, thậm chí cho cả thầy thuốc. Hiện tại còn thiếu các nghiên cứu tổng hợp về đặc điểm ngộ độc các ma túy mới nổi, đa số là những chất gây nghiện tổng hợp, vì vậy chúng tôi tiến hành nghiên cứu với mục tiêu: Mô tả đặc điểm lâm sàng, cận lâm sàng của bệnh nhân ngộ độc ma túy không phải nhóm opi tại Trung tâm Chông độc Bệnh viện Bạch Mai.

\section{II. ĐỐI TƯỢNG VÀ PHƯƠNG PHÁP NGHIÊN CỨU}

2.1. Đối tượng nghiên cứu: Bệnh nhân ngộ độc ma túy vào điều trị tại Trung tẩm Chống độc từ1/2017 đến 6/2019

* Tiêu chuẩn chọn bệnh nhân:Bệnh nhân có các tiêu chuẩn sau [3]

- Bệnh sử sử dụng ma túy (ma túy đá, thuốc lắc, ketamin, cần sa, ...)

- Biểu hiện lâm sàng ngộ độc ma túy

- Xét nghiệm độc chất nước tiểu thây ma túy.

\section{* Tiêu chuẩn loại trừ:}

- Bệnh nhân sử dụng đồng thời ma túy nhóm opi (heroin, morphin, methadon)

- Ngộ độc đồng thời các chất khác: thuốc, hóa chất bảo vệ thực vật...

\subsection{Phương pháp nghiên cứu}

2.2.1. Thiết kế nghiên cứu: Nghiên cứu mô tả.

2.2.2. Tiến hành nghiên cứu: thu thập số liệu theo mẫu bệnh án nghiên cứu thống nhất

- Đặc điểm chung: tuổi, giới, nghề nghiệp, tiền sử nghiện ma túy.

- Bệnh sử: loại ma túy sử dụng, hoàn cảnh, nơi và cách sử dụng.

- Đặc điểm lâm sàng: ý thức, mạch, huyết áp, sốt, mồ hôi, trương lực cớ, phản xạ gân xương, đồng tử... khi nhập viện và diễn biến

- Đặc điểm cận lâm sàng: huyết học, hóa sinh

- Các biến chứng, kết quả điều trị (khỏi, di chứng, tử vong).

- Xét nghiệm định tính các loại ma túy trong nước tiểu tại viện Giám định pháp $\mathrm{Y}$ bằng phương pháp sắc kí khí (GS). Sử dụng máy ủ mẫu GC6890N và máy phân tích mẫu ATG1888.

2.3. Xử lý số liệu. Số liệu được xử lý theo phương pháp thống kê y học, sử dụng phần mềm SPSS 20.0. So sánh giá trị 2 trung bình bằng Student test, so sánh nhiều giá trị trung bình bằng One way $A N O V A$, so sánh hai tỉ lệ bằng $X^{2}$, mức ý nghĩa thống kê 95\%. 


\section{KẾT QUẢ NGHIÊN CỨU}

\subsection{Một số đặc điểm chung}

Trong thời gian nghiên cứu, có 72 bệnh nhân đủ tiêu chuẩn chọn. Kết quả cho thấy:

- Loại ma túy bệnh nhân sử dụng:

- Amphetamin: 21 BN $(29,2 \%)$,

- Metamphetamin (MET): 16 BN (22,2\%),

- Methylenedioxymethamphetamine (MDMA), thuốc lắc: 14 BN $(19,4 \%)$

- Tetrahydrocannabinol (THC- có nhiều trong cần sa): 15 BN (20,8\%)

- Ketamin: 6 BN $(8,3 \%)$

- Đường dùng: Đường uống (chiếm 79,2\%), đường chích hoặc hít (29,8\%).

- Kết quả điều trị: Khỏi 66 BN $(91,7 \%)$, di chứng rối loạn tâm thần $6 \mathrm{BN}(8,3 \%)$

\subsection{1. Đặc điểm lâm sàng và cận lâm sàng}

\section{Bảng 1: Đặc điểm về ý thức}

\begin{tabular}{|c|c|c|c|c|c|c|c|}
\hline \multirow{3}{*}{ Loại ma túy } & \multicolumn{6}{|c|}{ Y thức } & \multirow{3}{*}{$\mathbf{p}$} \\
\hline & \multicolumn{2}{|c|}{ Kích thích, bồn chôn } & \multicolumn{2}{|c|}{ Vât vã } & \multicolumn{2}{|c|}{ Lú lân/ hôn mê } & \\
\hline & $\mathrm{n}$ & $\%$ & $\mathrm{n}$ & $\%$ & $\mathrm{n}$ & $\%$ & \\
\hline Amphetamin $(n=21)$ & 12 & 57,2 & 6 & 28,6 & 3 & 14,3 & \\
\hline $\operatorname{MET}(n=16)$ & 8 & 50,1 & 4 & 25,0 & 4 & 25,0 & \\
\hline MDMA $(n=14)$ & 9 & 64,3 & 2 & 14,3 & 3 & 21,4 & \\
\hline THC $(n=15)$ & 9 & 60,0 & 5 & 33,3 & 1 & 6,7 & $>0,0 b$ \\
\hline Ketamin $(n=6)$ & 4 & 66,7 & 0 & 0 & 2 & 33,3 & \\
\hline Tống $(\mathrm{n}=72)$ & 42 & 58,3 & 17 & 23,6 & 13 & 18,1 & \\
\hline
\end{tabular}

Nhận xét. Các BN đều có rối loạn về ý thức và tinh thần: kích thích bôn chồn (58,3\%), vật vã $(23,6 \%)$ và lú lẫn/ hôn mê $(18,1 \%)$. Tỉ lệ kích thích, bồn chồn cao nhất đối với BN sử dụng Ketamin $(66,7 \%)$, tiếp đến là MDMA (64,3\%). Tỉ lệ hôn mê cao trong nhóm sử dụng Ketamin (33,3\%). Tuy nhiên, rối loạn ý thức không đủ khác biệt giữa các loại ma túy $(p>0,05)$.

\section{Bảng 2: Đăc điểm dấu hiêu sinh tồn khác}

\begin{tabular}{|c|c|c|c|c|c|c|c|}
\hline Dấu hiệu & $\begin{array}{c}\text { Amphetamin }_{(\mathrm{n}}^{(1)} \\
\left.\mathrm{n}^{2} 21\right)\end{array}$ & $\begin{array}{c}\text { MET }^{(2)} \\
(n=16)\end{array}$ & $\begin{array}{c}\text { MDMA }^{(3)} \\
(\mathrm{n}=14)\end{array}$ & $\begin{array}{c}\operatorname{THC}^{(4)} \\
(\mathrm{n}=15) \\
\end{array}$ & $\begin{array}{c}\operatorname{Ketamin}^{(5)} \\
(\mathrm{n}=6)\end{array}$ & $\begin{array}{l}\text { Chung } \\
(\mathrm{n}=72)\end{array}$ & $\begin{array}{l}\mathbf{p}^{(1)(2)} \\
(3)(4)(5)\end{array}$ \\
\hline $\mathrm{N}$ & $16(76,2)$ & $11(68,8)$ & $8(57,1)$ & $13(86,7)$ & $5(83,3)$ & $53(73,6)$ & 0,05 \\
\hline & & & $4(28,6)$ & & $6,7)$ & & J, \\
\hline T & $\begin{array}{c}13 \\
(61,9 \% \\
\end{array}$ & $6(37,5 \%)$ & $\begin{array}{c}6 \\
(42,9 \%) \\
\end{array}$ & 9( & $\begin{array}{c}4 \\
(66,7 \%) \\
\end{array}$ & $\%)$ & $>0,05$ \\
\hline & $1(4,8 \%)$ & $1(6,3 \%)$ & 0 & & 0 & & $>0$ \\
\hline Tăng & $12(57,1 \%)$ & $7(43,8 \%)$ & $5(35,7 \%)$ & $6(40,0 \%)$ & $3(50,0 \%)$ & $33(45,8 \%)$ & $>0,0$ \\
\hline Giảm huyết áp & 0 & 0 & 0 & $2(13,3 \%)$ & 0 & $2(2,8 \%)$ & $>0,05$ \\
\hline
\end{tabular}

Nhận xét: Những dấu hiệu thường gặp là: nhịp tim nhanh ở 73,6\% số bệnh nhân, tăng huyết áp $45,8 \%$; sốt $43,1 \%$ và thở nhanh ở $52,8 \%$ số bênh nhân. Tỉ lệ các dấu hiệu khác nhau ở các loại ma túy nhưng không đủ khác biệt, $p>0,05$.

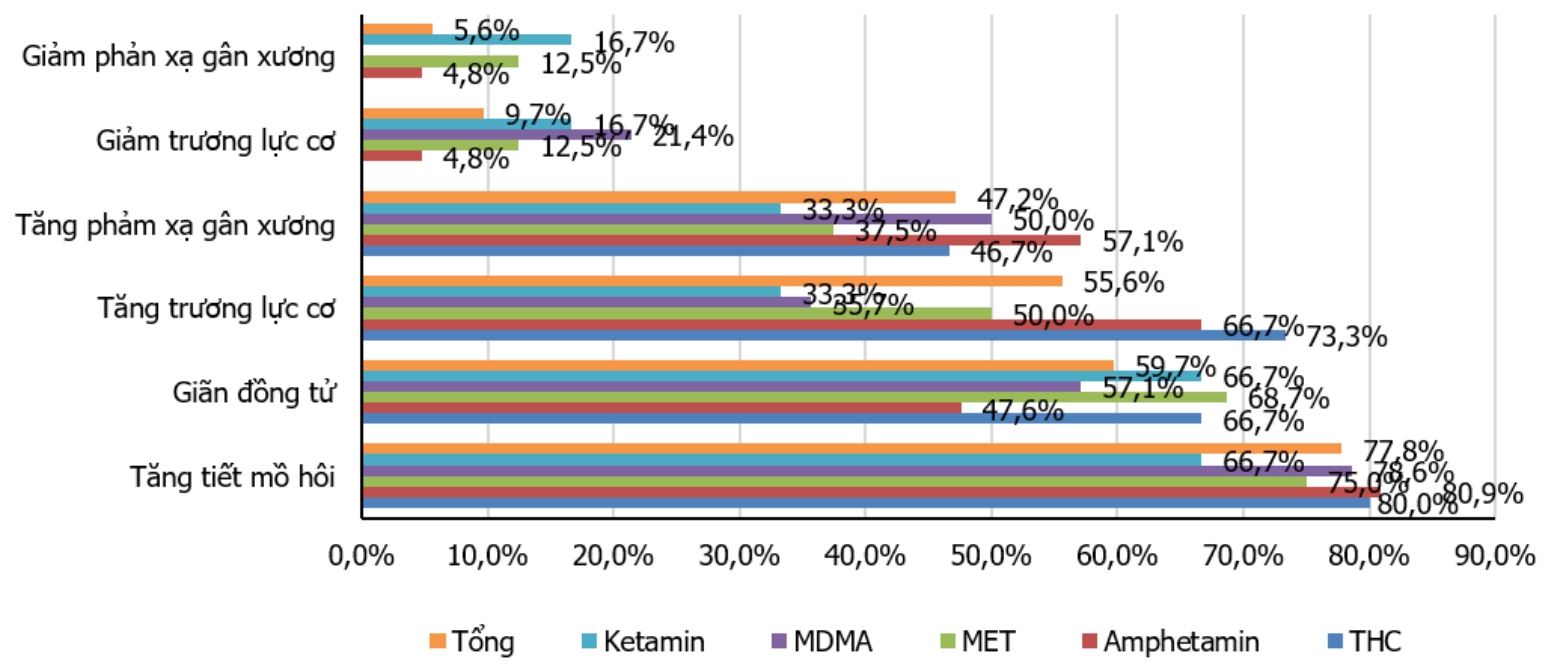

Biểu đồ 1: Một số đặc điểm lâm sàng 
Nhận xét: - Có $77,8 \%$ số BN có tăng tiết mồ hôi, cao nhất là sau dùng Amphetamin (80,9\%).

- Giãn đồng tử gặp ở 59,7\% số BN, tập trung nhiêuu ở nhóm dùng MET, THC và ketamin là $68,7 \%$, $66,7 \%$ và 66,7\%; ít nhất là ở BN sử dụng Amphetamin (47,6\%).

- Tăng trương lực cơ 55,6\% số BN, cao nhất ở nhóm THC (73,3\%), ít nhất là ketamin (33,3\%). Giảm trương lực cơ ít gặp $(9,7 \%)$, chủ yếu ở nhóm MDMA.

- Có $47,2 \%$ số BN tăng phản xạ gân xương, cao nhất ở nhóm amphetamin $(57,1 \%)$ và thấp nhất là ketamin (33,3\%). Giảm phản xạ gân xương ít gặp (5,6\%).

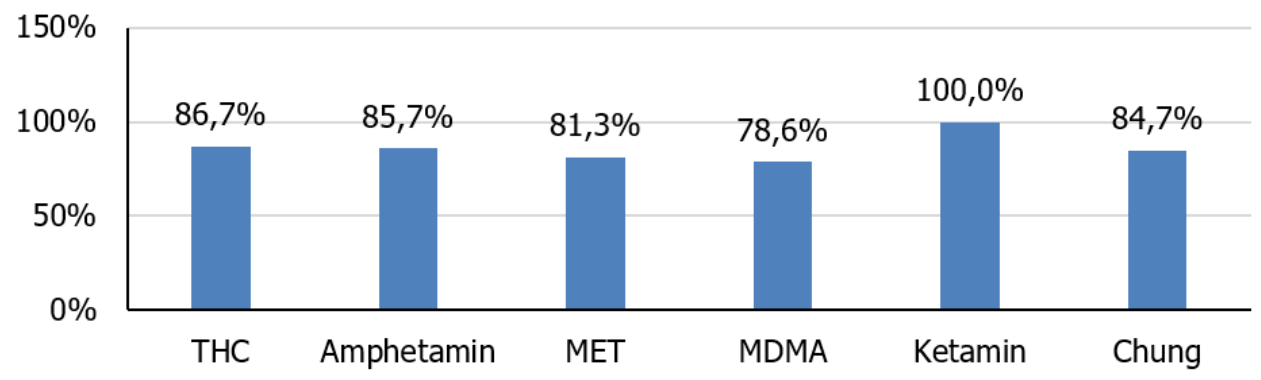

Biểu đồ 2: Hội chúng Serotonin

Nhận xét: BN sử dụng 5 loại ma túy trên đều có hội chứng Serotonin: nhiều nhất là Ketamin $(100 \%)$, ở các nhóm sử dụng THC, Amphetamin, MET, MDMA trong nghiên cứu lần lượt là $86,7 \%$; $85,6 \% ; 81,3 \%$ và 78,6\%.Cácdấu hiệu thường gặp như bồn chồn kích động, đổ mồ hôi, sốt, tăng huyết áp, tim đập nhanh, thở nhanh, tăng phản xạ gân xương, giãn đồng tử.

\section{Bảng 3. Đặc điểm về xét nghiệm huyêt học}

\begin{tabular}{|c|c|c|c|c|c|c|c|}
\hline Dấu hiệu & $\begin{array}{c}\text { Amphetamin }_{(\mathrm{n}}^{(1)} \\
(\mathrm{n}=21)\end{array}$ & $\begin{array}{l}\text { MET(2) } \\
(n=16)\end{array}$ & $\begin{array}{c}\text { MDMA }^{(3)} \\
(\mathrm{n}=14)\end{array}$ & $\begin{array}{c}\text { THCC(4) }^{(4)} \\
(n=15)\end{array}$ & $\begin{array}{c}\text { Ketamin }_{(\mathrm{n}=6)} \\
(\mathrm{s}\end{array}$ & $\begin{array}{l}\text { Chung } \\
(n=72)\end{array}$ & $\begin{array}{l}\mathbf{p}^{(1)(2)} \\
(3)(4)(5)\end{array}$ \\
\hline Tăn & $12(57,1 \%)$ & $6(37,5 \%)$ & $5(35,7 \%)$ & \begin{tabular}{|l}
$4(26,7 \%)$ \\
\end{tabular} & $3(50,0 \%)$ & $30(41,7 \%)$ & \\
\hline Tăn & $3(14$ & $2(12,5 \%)$ & 0 & $1(6,7 \%)$ & 0 & 3\%) & \\
\hline Giả & $1(4,8 \%)$ & $1(6,3 \%)$ & 0 & 0 & 0 & $8 \%)$ & \\
\hline Giảm & $3(14,3$ & $1(6,3 \%)$ & $2(14,3$ & $3(20,0 \%)$ & $1(16,7 \%)$ & 10 & $>0,0$ \\
\hline & & 7 & $1(7,1 \%)$ & 1 & $1(16,7 \%)$ & & \\
\hline RL đông máu & 0 & 0 & 0 & $16,7 \%)$ & 0 & $1(1,4 \%)$ & \\
\hline
\end{tabular}

Nhận xét: Những thay đối về huyết học gặp với tỉ lệ nhỏ và không khác biệt giữa các loại ma túy. Có $41,7 \%$ số bệnh nhân có tăng bạch cầu và $1 B N$ dùng THC có rối loạn đông máu.

\section{Bảng 4. Đặc điểm về xét nghiệm hóa sinh}

\begin{tabular}{|c|c|c|c|c|c|c|c|}
\hline Dấu hiệu & $\begin{array}{c}\text { Amphetamin }_{(\mathrm{n}}(\mathrm{n}=21) \\
\end{array}$ & $\begin{array}{c}\mathbf{M E T}^{(2)} \\
(\mathrm{n}=16)\end{array}$ & $\begin{array}{l}\text { MDMA }^{(3)} \\
(\mathrm{n}=14)\end{array}$ & $\begin{array}{c}\text { THC }^{(4)} \\
(\mathrm{n}=15)\end{array}$ & $\begin{array}{c}\text { Ketamin }^{(5)} \\
(\mathrm{n}=6)\end{array}$ & $\begin{array}{c}\text { Chung } \\
(\mathrm{n}=72)\end{array}$ & $\begin{array}{l}\mathbf{p}^{(1)(2)} \\
(3)(4)(5)\end{array}$ \\
\hline Hạ n & $2(9,5 \%)$ & $2(12,5 \%)$ & $1(7,1 \%)$ & 0 & 0 & $5(6,9 \%)$ & \\
\hline Hạ ka & $13(61,9 \%)$ & $6(37,5 \%)$ & $7(50,0 \%)$ & $10(66,7 \%$ & $5(83,3 \%)$ & $41(56,9 \%)$ & $>0,05$ \\
\hline Suy thân cấp & 0 & $2(2,5 \%)$ & 0 & 0 & 0 & $2(2,8 \%)$ & \\
\hline Tăng & $8(38,1 \%)$ & $5(31,3 \%)$ & $3(21,4 \%)$ & $5(33,3 \%)$ & 0 & $21(29,2 \%)$ & $>0,0$ \\
\hline Tăng AST & $7(33,3 \%)$ & $6(37,5 \%)$ & $3(21,4 \%)$ & $1(6,7 \%)$ & $2(33,3 \%)$ & $19(26,4 \%)$ & $>0,05$ \\
\hline & $8(38,1 \%)$ & $3(18,8 \%)$ & $3(21,4 \%)$ & $2(13,3 \%)$ & $3(50,0 \%)$ & $19(26,4 \%)$ & $>0,05$ \\
\hline Tăns & $9(42,9 \%)$ & $6(37,5 \%)$ & $4(28,6 \%)$ & $6(40,0 \%)$ & $3(50,0 \%)$ & $28(38,9 \%)$ & $>0,05$ \\
\hline Tiêu cơ vân & $1(4,8 \%)$ & $2(12,5 \%)$ & $3(21,4 \%)$ & $2(13,3 \%)$ & $2(33,3 \%)$ & $10(13,9 \%)$ & \\
\hline $\begin{array}{l}\text { Tăng Troponi } \\
\mathrm{T}(\mathrm{n}=30)\end{array}$ & $\begin{array}{c}2 \\
(22,2 \%)\end{array}$ & 0 & 0 & $\begin{array}{c}1 \\
(12,5 \%)\end{array}$ & 0 & $\begin{array}{c}3 \\
(10 \%\end{array}$ & 5 \\
\hline
\end{tabular}

Nhận xét: - Hạ natri máu gặp ở 6,9\% số BN, gặp chủ yếu nhóm MET và Amphetamin, không gặp ở BN dùng THC và ketamin. Ha kali gặp ở $56,9 \%$ số BN, cao nhất ở nhóm ketamin (83,3\%).

- Tăng Glucose ở $29,2 \%$ số BN, gặp nhiêu ở nhóm Amphetamin. AST và ALT đều tăng ở $26,4 \%$

- CK tăng ở 38,9\% số BN, cao nhất ở nhóm Ketamin $(50 \%)$ và thấp nhất là MDMA $(28,6 \%)$.
Tuy nhiên chỉ có $13,9 \% \mathrm{BN}$ có tiêu cơ vân và $12,5 \%$ có suy thận cấp.

- Chúng tôi chỉ kiểm tra được TroponinT ở 30 $B N$ và có $10 \%$ có tăng Troponin T

\section{BÀN LUẬN}

Trong 72 bệnh nhân ngộ độc ma túy không phải nhóm opi, chúng tôi thấygặp nhiều nhất là 
Amphetamin $21 \mathrm{BN}(29,2 \%)$, Metamphetamin 16 BN (22,2\%), MDMA 14 BN (19,4\%), THC 15 BN $(20,8 \%)$ và Ketamin là $6 \mathrm{BN}(8,3 \%)$. Thời gian gần đây, việc sử dụng các loại ma túy nhóm opi (heroin, morphine) được thay thế dần bằng các loại ma túy tổng hợp, chủ yếu trong các cuộc vui. Tại Tây Ban Nha, tác giả Gainza cũng nhận thấy việc sử dụng chất gây nghiện bất hợp pháp những năm gần đây có sự thay đổi. Dường như tỉ lệ sử dụng heroin giảm đi, thay vào đó là sự tăng lên và xuất hiện mới của cocain, dẫn xuất Amphetamin như thuốc lắc (MDMA) và Ketamin [4].

Amphetamin, methamphetamin, MDMA, paramethoxyamphetamin (PMA) và một số dẫn xuất của amphetamin là những ma túy tổng hợp có tác dụng kích thích và gây ảo giác được sử dụng phổ biến nhất hiện nay. MET là hoạt chất chủ yếu của dạng chất gây nghiện như ma túy đá (hàng đá), tên gọi chung cho các loại ma túy tổng hợp. THC-cần sa còn gọi là marijuana/ cannabis, là chất kích thích thần kinh từ cây Cannabis được sử dụng cho mục đích y tế hoặc giải trí.Ketamin thường có trong thuốc gây mê sử dụng trong y tế, tuy nhiên cũng là chất gây nghiện gần đây được sử dụng nhiêu hơn. Hiện nay, nhiêu loại ma túy tổng hợp được tìm thấy trong sản phẩm như "nước vui", "ma túy trà sữa", "bánh cần".

Ma túy chủ yếu sử dụng đường uống $(79,2 \%)$. Các loại ma túy cũ được sử dụng chủ yếu là hít, chích. Ma túy mới có nhiều hình thức sử dụng: THC có thể hút, hít hơi, trộn vào thực phẩm, hoặc như chất chiết xuất, ma túy đá (MET) có thể nuốt, hít, uống hoặc tiêm[5], [6].

- Đặc điểm lâm sang. Hầu hết các chất ma túy có tác dụng lên hệ tim mạch, hệ thần kinh trung ương. Các tác dụng trên tiêu hóa, tiết niệu cũng có thể gặp. Các triệu chứng lâm sàng thường trong 2 hội chứng hội chứng cường giao cảm và hội chứng serotonin[4], [7].

Các triệu chứng thần kinh thường gặp khi ngộ độc các loại ma túy này gồm lo lắng, tính khí dễ thay đổi, kích thích, hung hãn, ảo thị, ảo giác, loạn thần kiểu tâm thần phân liệt paranoid. Amphetamin có tác dụng kích thích làm giải phóng catecholamin đặc biệt là dopamin và norepinephrin ở đầu tận thần kinh, ức chế tái hấp thu catecholamin và ức chế monoamine oxidase. Amphetamines đặc biệtlà MDMA, PMA, fenfluramin, và dexfenfluramin, cũng gây giải phóng serotonin và ức chế tái hấp thu serotonin tại xynap thần kinh [5].Các triệu chứng về ý thức găp trong nghiên cứu của chúng tôi là kích thích bồn chồn $(58,3 \%)$, vật vã $(23,6 \%)$ và hôn mê
$(18,1 \%)$. Tỉ lệ có kích thích, bồn chồn cao nhất đối với người sử dụng Ketamin $(66,7 \%)$, tiếp đến là MDMA $(64,3 \%)$. Tỉ lệ hôn mê cao trong nhóm sử dung Ketamin (33,3\%). Măc dù sự khác biệt khồng đủ có ý nghĩa nhưng có thể thây các ma túy trong nghiên cứu đều gây rối loạn ý thức ở các mức độ khác nhau. Triệu chứng thần kinh trung ương là một trong các triệu chứng chínhkhi ngộ độc chất gây nghiện. Các dấu hiệu có thể thay đổi từ lơ mơ, ngủ gà tới hôn mê. Có chất có tác dụng hỗn hợp kích thích - đối kháng gây phản ứng bồn chồn hay thậm chí loạn thần do kích thích thụ thể sigma [4], [5], [7].

Cần sa có tác dụng lên tâm thần và sinh lý, gây thư giãn và hưng phấn ("bay bổng"), thay đổi nhận thức, tăng ham muốn tình dục, ở liều cao có thể gây ảo tưởng thị giác, thính giác, tách rời thực tế [6]. Ketamin là đối kháng N-methylD-aspartat, ức chế tái nhập dopaminh và chủ vận thụ thể mu-opioid. Đồng thời, Ketamin cũng làm cản trở con đường của não trước khi phong tỏa cảm giác bản thể, ức chế chọn lọc hệ thống đồi thị võ não trước khi ức chế các trung tâm não (hệ viền và hoạt hóa lưới) [7].

Các triệu chứng của ngộ độc chất gây nghiện trên hệ tuần hoàn có thể gặp rối loạn tăng hoặc giảm huyết áp, nhịp nhanh hoặc chậm, loạn nhịp, thiếu máu, nhồi máu cơ tim, co thắt mạch,... Kết quả nghiên cứu cho thây nhịp tim nhanh là triệu chứng gặp ở phần lớn các $B N$ $(73,6 \%)$. Trong đó nhiều nhất là ở người sử dung THC (86,7\%), Ketamin (83,3\%), Amphetamin $(76,2 \%)$, MET (68,8\%) và MDMA (57,1\%). Gần một nửa số BN có rối loạn huyết áp, tỉ lệ tăng huyết áp là $45,8 \%$ vànhiều nhất ở nhóm dùng Amphetamin $(57,1 \%)$. Chỉ có $2 \mathrm{BN}$ có tụt huyết áp sau dùng THC. Chất gây nghiện có rất nhiều tác dụng trực tiếp trên hệ thống tim mạch. Tăng huyết áp và mạch do cường giao cảm. Tụt huyết áp có thể do giãn tĩnh mạchgây giảm cả huyết áp tâm thu và tâm trương, dấu hiệu này thường không thấy rõ khi bệnh nhân nằm. Không có tác dụng trên tính co bóp và tính dẫn truyền của cơ tim ngoại trừ propoxyphen, meperidin hoặc pentazocin. Các loạn nhịp tim cũng thường là do thiếu ôxy. Tuy nhiển, nểu tụt huyết áp nhiêu cân tìm thêm các nguyên nhân khác như ngộ độc đồng thời các chất khác, sốc giảm thể tích (chẩn thương),tổn thương tim...[4].

Tăng thân nhiệt cũng là một triệu chứng thần kinh trung ương hay gặp đổi với những bệnh nhân ngộ độc chất gây nghiện. Sốt là triệu chứng gặp ở gần một nửa số đối tượng nghiển cứu $(43,1 \%)$ do tăng vận động, cường giao cảm. 
Tỉ lệ này cao nhất trong nhóm sử dụng Ketamin $(66,7 \%)$ và thấp nhất trong nhóm dùng MDMA $(28,6 \%)$. Tuy vậy, không có sự khác biệt có ý nghĩa thống kê về tỉ lệ có sốt giữa các nhóm đối tượng sử dụng các loại ma túy khác nhau.

Các triệu chứng giao cảm ở các bệnh nhân gồm vã mồ hôi, thở nhanh, đồng tử giãn, run, buồn nôn...Đa số đối tượng nghiên cứu sử dụng tất cả các loại ma túy trong nghiên cứu có tăng tiết mồ hôi $(77,7 \%)$, trong đó cao nhất là những người dùng Aphetamin $(80,9 \%)$ và THC $(80,0 \%)$, thấp nhất là ở nhóm dùng Ketamin $(66,7 \%)$. Giãn đồng tử gặp ở $59,7 \%$ số $B N$ và nhiêu hơn ở nhóm dùng MET, THC và Ketamin là $68,7 \% ; 66,7 \%$ và $66,7 \%$. Trong nghiên cứu này, không thây sự khác biệt có ý nghĩa về các triệu chứng giao cảm giữa các nhóm sử dụng ma túy khác nhau.Triệu chứng cường giao cảm được nhiều tác giả ghi nhận trong ngộ độc các ma túy tổng hợp [4], [5].

Tỉ lệ có tăng trương lực cơ trong nghiên cứu là $55,6 \%$. Tỉ lệ này giảm dần theo thứ tự ở người dùng THC $(73,3 \%)$, Amphetamin $(66,7 \%)$, MET $(50 \%)$, MDMA $(35,7 \%)$ và Ketamin (33,3\%). 47,2\% số bệnh nhân có tăng phản xạ gân xương, trong đó cao nhất ở nhóm sử dụng Amphetamin $(57,1 \%)$ và thấp nhất trong nhóm dùng Ketamin (33,3\%). Chưa tới $10 \%$ số đối tượng nghiên cứu có giảm trương lực cơ $(9,7 \%)$. Mức độ nặng của ngộ độc amphetamin tăng theo liều lượng dùng và giảm với mức độ dung nạp của người dùng. Có những người dung nạp tới $5 \mathrm{mg} / \mathrm{ngày} ;$ gấp 100 lần liều điều trị tối đa hằng ngày. Ngộ độc amphetamin gây tử vong thường liên quan đến co giật và hôn mê [4].

Người bệnh sử dụng và ngộ độc chất gây nghiện thường có các triệu chứng Serotonin như bồn chồn kích động, đổ mồ hôi, sốt, tăng huyết áp, tim đập nhanh, thở nhanh, tăng phản xạ gân xương, giẫn đồng tử [6]...Hầu như bệnh nhẩn sử dụng 5 loại ma túy trong nghiên cứu đều có hội chứng Serotonin đặc biệt là ngộ độc Ketamin. Tỉ lệ có hội chứng Serotonin ở các nhóm sử dụng THC, Amphetamin, MET, MDMA trong nghiên cứu lần lượt là $86,7 \% ; 85,6 \% ; 81,3 \%$ và $78,6 \%$.

- Cận lâm sàng. Những thay đổi về huyết học gặp với tỉ lệ nhỏ và không khác biệt giữa các loại ma túy. Có $41,7 \%$ số bệnh nhân có tăng bạch cầu. Trên thực tế, tăng bạch cầu là phản ứng chung của nhiểu tác nhân ngộ độc.

Rối loạn điện giải hạ natri máu gặp ở 6,9\% số bệnh nhân, gặp chủ yếu nhóm MET và Amphetamin, không gặp ở bệnh nhân dùng THC và ketamin. Yếu tố chính gây hạ natri máu là sự bài tiết không thích hợp của arginine vasopressin (AVP) do các chất chuyển hóa của thuốc lắc gây ra. Thuốc lắc gây ra các tác dụng tim mạch thoáng qua với nhiệt độ cơ thể tăng, nhịp tim nhanh, đổ mồ hôi nhiều, nóng bừng, khô miệng và tăng cảm giác khát. Tác giả Van Dijken và cộng sự năm 2013 nhận thấy tî lệ hạ natri máu ở bệnh nhân ngộ độc ma túy là $26,7 \%$ [8].Hạ kali gặp ở $56,9 \%$ số BN, cao nhất ở nhóm sử dụng ketamin $(83,3 \%)$, giảm dần ở các nhóm dùng THC (66,7\%), Amphetamin (61,9\%), MDMA $(50 \%)$ và $\mathrm{MET}(37,5 \%)$, không khác biệt giữa các loại ma túy $(p>0,05)$.

Tăng Glucose ở $29,2 \%$ số BN, gặp nhiều ở nhóm Amphetamin. Tăng đường máu là tình trạng thường gặp ở các bệnh nhân cấp cứu. Ở bệnh nhân nặng có hiện tượng bề mặt tế bào tăng sản sinh các protein có tính chất gây tăng cortisol, catecholamin, growth hormone gây tình trạng tăng đường huyết.

Tăng CK ở 38,9\% số BN, cao nhất ở nhóm Ketamin $(50 \%)$ và thấp nhất là MDMA $(28,6 \%)$. Tuy nhiên chỉ có $13,9 \% \mathrm{BN}$ có tiêu cơ vân và $12,5 \%$ có suy thận cấp. Tiêu cơ vân thường do các bệnh nhân bị kích động, vận động nhiều, run cơ. Tiêu cơ vân cũng là nguyên nhẩn khá thường gặp cả trong ngộ độc ma túy và hội chứng cai ma túy và cai rượu.

\section{KẾT LUẬN}

Nghiên cứu 72 bệnh nhân ngộ độc ma túy không phải nhóm opi, chúng tôi thây: Loại ma túy không phải nhóm opi thường gặp tại Trung tâm Chống độc là: Amphetamin (29,2\%), MET $(22,2 \%)$, MDMA $(19,4 \%)$, THC $(20,8 \%)$, Ketamin (8,3\%).

Dấu hiệu lâm sàng chủ yễuvề tim mạch và thần kinh trung ươngtrong hội chứng cường giao cảm và hội chứng serotonin: Nhịp tim nhanh $(73,6 \%)$; tăng huyết áp $(45,8 \%)$, sốt $(43,1 \%)$; Rối loạn ý thức $100 \%$ (kích thích $58,3 \%$, vật vã $23,6 \%$ và $18,1 \%$ lú lẫn/hôn mê); tăng tiết mồ hôi $(77,8 \%)$, giãn đồng tử $(59,7 \%)$, tăng trương lực cơ $(55,6 \%)$, tăng phản xạ gân xương $(47,2 \%) ; 84,7 \%$ có hội chứng serotonin. Cận lâm sàng: tăng bạch câuu $41,7 \%$, tăng CK $38,9 \%$; tiêu cơ vân $13,9 \%$; suy thận cấp $12,5 \%$; tăng troproninT 10\%. Kết quả điều trị: Khỏi $66 \mathrm{BN}$ $(91,7 \%)$, di chứng rối loạn tâm thần 6 BN $(8,3 \%)$.

\section{TÀI LIỆ THAM KHẢO}

1. United Nations Office on Drugs and Crime (UNODC) 2016. World Drug Report 2016.

2. Nguyển Thanh Long và và cộng sự. Hành vi nguy cơ lây nhiểm và tỳ lệ nhiếm HIV trong nhóm 
nghiện chích ma túy tại khu vực nông thôn miên núi tỉnh Bắc Giang, năm 2010. Tạp chí Y học thực hành2010, số 742-743: 197-200

3. Nguyễn Thị Dụ, Định hướng chung chẩn đoán và xứ trí ngộ độc cấp, Tư vấn chẩn đoán và xử trí nhanh ngộ độc cấp. Nhà xuất bản Y học Hà Nội. 2004; 9-2 2

4. Gainza I., Nogue S., Martinez Velasco C.,et al (2003), "Drug poisoning", An Sist Sanit Navar, 26 (1): $99-128$

5. Spiller H. A., Hays H. L., Aleguas A. (2013), "Overdose of drugs for attention-deficit hyperactivity disorder: clinical presentation, mechanisms of toxicity, and management", CNS Drugs, 27(7), tr. 531-43.

6. Fogel C Osborne GB (2008), "Understanding the motivations for recreational marijuana use among adult Canadians", Substance Use \& Misuse,43(3-4), 539-72.

7. Robert J Hoffman (2020), "Ketamine poisoning", Uptodate 2020.

8. Geetruida D van Dijken, Renske E Blom, Ronald J Hené, et al (2013), High incidence of mild hyponatraemia in females using ecstasy at a rave party, Nephrol Dial Transplant, 28(9):2277-83.

\section{MộT Số ĐĂC ĐIỂM LÂM SÀNG, CÂ̂N LÂM SÀNG VÀ KẾT QUẢ CHỤP ĐộNG MACH VÀNH QUA DA Ở BỆNH NHÂN NHỒI MÁU CO' TIM CẤP}

\section{TÓM TẮT}

Nhồi máu cơ tim cấp là một cấp cứu nội khoa với nhiều biến chứng năng như sốc tim, rối loan nhip tim. Chụp động mạch vành qua da là biện pháp để xác đinh vị trí, mức đô tổn thương động mach vành đồng thời can thiệp tái thông động mạch vành. Mục tiêu: Mô tả đặc điểm lâm sàng, cận lâm sàng và kết quả chụp mạch vành qua da ở bệnh nhân nhồi máu cơ tim cấp tại Bệnh viện hữu nghị Đa khoa Nghệ An. Đối tượng và phường pháp nghiên cứu: Nghiên cứu mô tả cắt ngang được thực hiên trên 62 bênh nhân nhồi máu cơ tim cấp điều trị tại Bệnh viện hữu nghị đa khoa Nghê An. Kết quả: Tuổi trung bình là $72,5 \pm$ 12,1 tuổi, nam giới chiếm $70,79 \%$. Đa số bệnh nhân có một hoặc nhiêuu yếu tố nguy cơ đi kèm: tăng huyết áp $(51,61 \%)$, rối loạn lipid máu $(25,80 \%)$, hút thuốc lá $(24,90 \%)$, đái tháo đường $(22,50 \%)$, lạm dụng rượu (4,84\%). Thời gian từ lúc đau ngực đến lúc nhập viện: trước 12 giờ là $58,06 \%$, trước 24 giờ là $67,74 \%$, sau 24 giờ 32,26\%. Tỷ lệ hẹp một động mạch vành là $41,93 \%$, hai động mạch vành là $45,16 \%$, hẹp ba động mach vành là $11,91 \%$. Trong đó, $75,81 \%$ có hep LAD, $56,45 \%$ có hẹp RCA, 43,55\% có hẹp LCX và $1,61 \%$ có hep đông mach phân giác. Kết luân: Đa số bênh nhân nhồi máu cơ tim cấp có một hoặc nhiều yếu tỗ nguy cơ tim mạch đi kèm. Tỷ lệ bệnh nhân đến bệnh viện có khả năng can thiệp mạch sau 24 giờ kể từ khi đau ngực còn cao $(32,26 \%)$. Tỷ lệ hẹp một động mạch vành là $41,93 \%$, hai động mạch vành là $45,16 \%$, hẹp ba động mạch vành là $11,91 \%$ và đa số là hẹp độ 4 và độ 5 .

Tư khóa: Nhồi máu cơ tim cấp, chụp động mạch vành qua da

${ }^{1}$ Trường Đại học Y khoa Vinh,

${ }^{2}$ Bệnh viện Hữu nghị đa khoa Nghệ An

Chịu trách nhiệm chính: Nguyễn Văn Tuấn

Email: tuanminh1975@gmail.com

Ngày nhận bài: 2.3.2021

Ngày phản biên khoa học: 22.4.2021

Ngày duyệt bài: 4.5.2021
Nguyễn Văn Tuấn ${ }^{1}$, Phạm Hồng Phương²

\section{SUMMARY}

THE CLINICAL, SUBCLINICAL FEATURES AND RESULTS OF PERCUTANEOUS ANGIOGRAPHY IN PATIENTS WITH MYOCARDIAL INFARTION AT THE NGHE AN GENERAL HOSPITAL

Acute myocardial infarction is a medical emergency with serious complications such as cardiogenic shock and arrhythmia. Percutaneous coronary angiography is a measure to determine the location and extent of coronary artery damage and interventions to re-open coronary arteries. Objectives: To describe the clinical and subclinical features and the results of percutaneous coronary angiography in patients with acute myocardial infarction at the Nghe An General Hospital. Results: The average age was $72.5 \pm 12.1$ years, and male accounted for $70.79 \%$. The majority of patients had one or more associated risk factors: hypertension $(51.61 \%)$, dyslipidemia $(25.80 \%)$, smoking $(24.90 \%)$, diabetes ( $22.50 \%$ ), abuse of alcohol (4.84\%). The time from chest pain to hospital admission: before 12 hours was $58.06 \%$, before 24 hours was $67.74 \%$, and after 24 hours was $32.26 \%$. The rate of the stenosis of one coronary arteries is $41.93 \%$, the stenosis of two coronary arteries is $45.16 \%$, the stenosis of three coronary arteries is $11.91 \%$. Of which, $75.81 \%$ had LAD stenosis, $56.45 \%$ had RCA stenosis, $43.55 \%$ had LCX stenosis. Conclusion: Most people with acute myocardial infarction have one or more associated cardiovascular risk factors. The proportion of patients going to the hospital that is capable of performing vascular intervention after 24 hours since chest pain remains high $(32,26 \%)$. The rate of one coronary stenosis is $41,93 \%$, two coronary stenosis is $45,16 \%$, three coronary stenosis is $11,91 \%$ and the majority is grade 4 and 5 stenosis.

Keywords: Acute myocardial infarction, percutaneous coronary angiography

I. ĐĂT VẤN ĐỀ

Nhồi máu cơ tim (NMCT) là một cấp cứu nội 